\title{
Relationship Emotional Intelligence with Conflict Management in Employees of PT. Aspacindo Kedaton Motor
}

\author{
Farida Hanum Siregar \\ Medan Area University, North Sumatera, Indonesia \\ siregarfarida25@gmail.com
}

\section{Abstract}

The aim of the study is to find out the relationship emotional Intelligence with Conflict Management in Employees of Pt. Aspacindo Kedaton Motor. The research approach used in this study is a quantitative approach using correlation or relationship tests. Correlation research is research that aims to investigate the extent to which variations in one variable are related to variations in one or more other variables. The result of research on employees who have high conflict management and emotional intelligence are also classified as high. This can be seen from the $S D$ results of 6.056, the hypothetical mean value of conflict management at 62.5, and the empirical mean of 74.66. Furthermore, the results of elementary emotional emotional intelligence amounted to 10.38 , the mean hypothetical value was 72.5 and the empirical mean was 88.82 .

Keywords

emotional intelligence; conflict management; employees

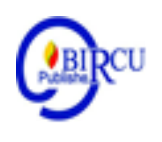

\section{Introduction}

Employees who have skills in emotional intelligence will be able to read other people's feelings and have social skills which means they are able to manage the feelings of others well. Very emotional intelligence important is owned by every employee in an organization that will help employees connect with other employees and share information and to manage conflicts that arise in carrying out tasks in their work.

As expressed in research (Cooper and Sawaf, 2002) that emotional intelligence is self control, enthusiasm, and perseverance as well as the ability to motivate yourself and survive facing frustration, regulating moods, empathy, and the ability to resolve conflicts. In these various styles the researchers have conducted various studies on the relationship between emotional intelligence and conflict management styles, the relationship between conflict management styles and performance and the relationship between emotional intelligence and performance mediated by conflict management styles.

Political marketing can also be categorized as one form of political persuasion by parties and politicians to win the hearts of the people. As also confirmed by Arifin, that among the methods most often used by politicians to subdue audiences, besides informative methods, education and coercive is a method of persuasion. Persuasion is one of the most basic forms of communication. (Azhar, 2018)

This research was conducted on employees at PT. Aspacindo Kedaton Motor has been in the automotive business for more than 10 years as a Yamaha motorcycle dealer. Service coverage is centered in the northern part of North Sumatra (currently entering 4 provinces, namely North Sumatra NAD, Riau and Riau Islands). Success certainly does not come just like that. With no more than 10 core troops in the first year, PT. Aspacindo Kedaton Motor then processes intuition and vision with struggle and action. 
Precisely on August 25, 2000, PT. Aspacindo Kedaton Motor confirmed its determination to make the big name of YAMAHA, which had been absent 3 (three) years from the Indonesian automotive world. 5 (five) years is not a short period of time to establish the foundation of this company. Like the philosophy of bamboo plants, PT. Aspacindo Kedaton Motor builds strong roots by building a strong management system. Flexible but strong like bamboo sticks that are elastic but not easily broken. His expertise revived the YAMAHA brand which was paralyzed in the 90s, contributing a large share in the market share of Japanese motorcycle sales on a national scale. Finally, after a long struggle, in early 2007, YAMAHA managed to break the motorcycle market record in Indonesia. Along with these achievements, PT. Aspacindo Kedaton Motor has confirmed the greatness of its name by designing a new company identity that is summarized in this guideline standard.

Thus the company is selling Yamaha motorcycle products with several types of motorcycles such as Yamaha V-Ixion, Jupiter Z, New Vega R, Mio Sporty, New RX-King, Jupiter MX, Scorpio $Z$ and so on in the city area of Medan. The parties that manage the company are arranged in such a way in an organizational structure. The organizational structure is a certain basic framework that shows the relationship of organizational units and individuals who are in the organization. Through the organizational structure, the duties, authorities and responsibilities of each official can be known clearly and firmly, so that it is expected that each organizational unit can work together in harmony. With a good organizational structure, will determine the success or failure of the company in achieving company goals, so that the efforts made can run efficiently and effectively led by a branch manager (Branch Manager). The branch head is responsible to the head at the head office.

Based on the initial phenomenon of researchers through observation and interviews with informants stated that, the relationships between coworkers can often lead to conflict. One of the conflicts that often occur such as data gaps received about the position of assets (motorcycle sales) and delays in information, thus slowing the completion of work and ordering goods needed by the community. Furthermore, the resource person stated that at PT. Aspacindo Kedaton Motor explained, no less than 50\% of all employees experienced conflicts. Some employees have even experienced conflicts since working for a month or two and continue to this day.

Conflicts can have a negative impact on the parties directly involved or on the people around them if they are not resolved with proper conflict management. Conflict management is said to be appropriate when it is able to control and change conflicts in order to achieve conflict outcomes that are beneficial or at least not detrimental. From the results of observation, researchers see the conflict management style used by employees tends to be in competition and withdraw. Competition is carried out by employees who have the power to suppress opponents of conflict while employees who do not have the ability to fight tend to withdraw. Conflict management used does not seem to be able to assist employees in producing the desired conflict output.

\section{Research Method}

\subsection{Definition of Conflict Management}

According to Susan (2009) conflict management is defined as an effort to prevent violence in conflict. The use of power and authority is part of the conflict strategy of the dominant group. This is in line with the opinion expressed by (Wirawan, 2010) which provides a definition of conflict management as the process of parties involved in the conflic 
or third parties formulate conflict strategies and apply them to control the conflict in order to produce the desired resolution. In line with the two opinions above, (Ross, 1993) provides a definition that conflict management is the steps taken by the perpetrators or third parties in directing disputes on certain outcomes that can be in the form of conflict resolution and produce calm, positive things, creative consensus or aggressive.

From expert opinion related to conflict management, this study uses the notion of conflict management based on the opinion of Wirawan where conflict management is defined as the process of parties involved in the conflict or third parties formulating conflict strategies and applying them to control conflict in order to produce the desired resolution. The reason for taking the understanding of conflict management according to Wirawan, is because the opinion expressed by Wirawan is relevant to what will be investigated by researchers where conflict management aims to reduce the negative impact of conflict.

From some of the expert opinions above, the researcher concludes that conflict management is a step that is chosen and taken by the parties involved in the conflict or outside parties to manage the conflict that aims to reduce the negative impact of the conflict for the parties involved in the conflict.

\subsection{Definition of Emotional Intelligence}

The term emotional intelligence was first put forward by two psychologists namely Salovey and Mayer which was later popularized by Goleman in 1999. Salovery and Mayer (1990) define emotional intelligence as: "a type of social emotional intelligence that involves the ability to monitor social feelings in oneself and other people, sort through everything and use this information to guide their thoughts and actions ". Cooper and Sawaf (1998) say that emotional intelligence is the ability to feel, understand, and selectively apply emotional power and sensitivity as a source of energy and humane influence.

In contrast to Harmoko (2005), emotional intelligence can be interpreted as the ability to recognize, process, and express appropriately, including to motivate yourself, recognize the emotions of others, and build relationships with others. In line with the above opinion, (Goleman, 2001) defines emotional intelligence as the ability to motivate yourself, and survive facing frustration, controlling impulses, and not exaggerating pleasure, regulating moods, and keeping the stress load from crippling thinking ability, empathize and pray.

From three expert opinions related to emotional intelligence, this study uses the notion of emotional intelligence based on the opinion of Goleman where emotional intelligence is defined as the ability to motivate yourself, and survive facing frustration, controlling impulses, and not exaggerating pleasure, regulating mood, and keep the stress load from paralyzing the ability to think, empathize and pray. The reason researchers use the definition of emotional intelligence from Goleman, because the theory of emotional intelligence put forward Goleman has aspects that are used to express emotional intelligence on the subject.

\subsection{Definition of Emotional Intelligence}

With advances in the industry, there is naturally increasing competition between companies. Therefore, companies often demand their employees to increase their productivity. Employees who experience conflicts can experience a decline in morale and their performance is not optimal so that it can interfere with the plans and desired goals of the company.

Conflict is a difference of opinion resulting from the availability of two or more programs that this action may not only be inevitable but also a valuable part of life. This helps to ensure that different possibilities are considered correct, and the possibility that further programs of action can result from the discussion of alternatives have been 
recognized. Also, conflict often means that the actions chosen are tested at an early stage, thereby reducing the risk of missing important defects that may arise later. Thus the conflict is the mismatch between one opinion with another opinion.

Conflict becomes a dangerous and disruptive force every time a person is risking on the outcome. The more conflict develops, the deeper the risk, the bitter the conflict becomes and the less easy it is to reach a solution. Unable to make a decision because no one dares to make a concession for fear (maybe justified) that this will be used by the other party as a victory and a bridge for further progress. In other words, don't play around with conflicts before they become bigger and more dangerous.

\section{Research Method}

The research approach used in this study is a quantitative approach using correlation or relationship tests. Correlation research is research that aims to investigate the extent to which variations in one variable are related to variations in one or more other variables, based on Azwar's correlation coefficient (2005). This study was conducted to examine the relationship between two variables including the independent variable, emotional intelligence and the dependent variable, conflict management.

a. This study consists of two variables, namely:

1. Independent Variable (X) : Emotional intelligence

2. Dependent Variable (Y) : Conflict management

Conflict management is a step that is chosen and carried out by parties involved in the conflict or outsiders to manage conflict that aims to reduce the negative impact of the conflict for the parties involved in the conflict. Measuring instruments used are aspects of conflict management. According to Robbins (2002), they are as follows: 1. Competing, 2. Kalaborasia or problem solving, 3. Avoidance, 4. Friendly accommodations or helpers, 5. Compromise or conciliator.

The choice of answers provided by researchers includes Very Appropriate (SS), Appropriate (S), Unsuitable (TS), Very Unsuitable (STS). The four answer choices aim to make it easier for respondents to choose answers according to the reality experienced. The statements compiled consist of two component items, namely favorable (statements supporting) and unfavorable (statements not supporting). In the favorable statement the answer is very appropriate (SS) has a score of 4 , accordingly (S) has a score of 3 , does not match (TS) has a score of 2 and is not very appropriate (STS) has a score of 1 . In the unfavorable statement the answer is very suitable (SS) has score 1, accordingly (S) has a score of 2, inappropriate (TS) has a score of 3 and very inappropriate (STS) has a score of 4.

\section{b. Emotional Intelligence Scale}

The measuring instrument used to measure emotional intelligence is a scale emotional intelligence designed by researchers based on aspects of emotional intelligence according to (Goleman, 2001). Self-awareness, self-regulation, motivation, empathy, social skills.

The choice of answers provided by researchers includes Very Appropriate (SS), Appropriate (S), Unsuitable (TS), Very Unsuitable (STS). The four answer choices aim to make it easier for respondents to choose answers according to the reality experienced. The statements compiled consist of two component items, namely favorable (statements supporting) and unfavorable (statements not supporting). In the favorable statement the answer is very appropriate (SS) has a score of 4, accordingly (S) has a score of 3, does not match (TS) has a score of 2 and is not very appropriate (STS) has a score of 1 . In the 
unfavorable statement the answer is very suitable (SS) has score 1, accordingly (S) has a score of 2, inappropriate (TS) has a score of 3 and very inappropriate (STS) has a score of 4.

\section{Discussion}

Table 1. Items Distribution Scale Conflict Management

\begin{tabular}{|c|c|c|c|c|c|}
\hline \multirow{2}{*}{ No. } & \multirow{2}{*}{ Aspect } & \multirow{2}{*}{ Indikator } & \multicolumn{3}{|c|}{ Item Number } \\
\hline & & & Favorable & Unfavorable & Total \\
\hline \multirow[t]{2}{*}{1.} & \multirow{2}{*}{$\begin{array}{l}\text { Competing or } \\
\text { competition }\end{array}$} & Power-oriented style & 9 & 14 & 2 \\
\hline & & win the conflict & 4,23 & 1,26 & 4 \\
\hline \multirow[t]{2}{*}{2.} & \multirow{2}{*}{$\begin{array}{l}\text { Kalaborasia or } \\
\text { problem } \\
\text { solving }\end{array}$} & Look for a solution & 18,27 & 25,31 & 4 \\
\hline & & $\begin{array}{l}\text { accept other people's } \\
\text { opinions }\end{array}$ & 6,11 & 2,16 & 4 \\
\hline \multirow[t]{2}{*}{3.} & \multirow[t]{2}{*}{ Avoidance } & Avoid conflict & 17 & 3 & 2 \\
\hline & & Appreciate the decision & 21 & 24 & 2 \\
\hline \multirow[t]{2}{*}{4.} & \multirow[t]{2}{*}{ Accommodation } & $\begin{array}{l}\text { Not concerned with } \\
\text { personal interests }\end{array}$ & 10,12 & 8,15 & 4 \\
\hline & & Lack of firm & 5 & 20 & 2 \\
\hline \multirow[t]{2}{*}{5.} & \multirow[t]{2}{*}{ Compromise } & $\begin{array}{l}\text { Looking for a middle } \\
\text { ground }\end{array}$ & 19,28 & 13,29 & 4 \\
\hline & & $\begin{array}{l}\text { Ability to negotiate } \\
\text { listening well }\end{array}$ & 7,30 & 22,32 & 4 \\
\hline \multicolumn{3}{|c|}{ Total } & 16 & 16 & 32 \\
\hline
\end{tabular}

Table 2. Item Distribution Emotional Intelligence Scale

\begin{tabular}{|c|c|c|c|c|c|}
\hline \multirow[t]{2}{*}{ No } & \multirow{2}{*}{ Aspect } & \multirow{2}{*}{ Indikator } & \multicolumn{3}{|c|}{ Item Number } \\
\hline & & & Favorable & Unfavorable & Total \\
\hline \multirow[t]{2}{*}{1} & \multirow[t]{2}{*}{ Self-awareness } & $\begin{array}{l}\text { Recognize and understand } \\
\text { your own emotions }\end{array}$ & 7,30 & 8,35 & 4 \\
\hline & & $\begin{array}{l}\text { Understand the causes of } \\
\text { emotions }\end{array}$ & 3 & 22 & 2 \\
\hline \multirow[t]{2}{*}{2} & \multirow[t]{2}{*}{ Self-regulation } & Control emotions & 29,19 & 16,25 & 4 \\
\hline & & $\begin{array}{l}\text { Express emotions } \\
\text { appropriately }\end{array}$ & 2 & 5 & 2 \\
\hline \multirow[t]{2}{*}{3} & \multirow[t]{2}{*}{ Motivation } & Optimistic & 28,33 & 3,11 & 4 \\
\hline & & $\begin{array}{l}\text { The drive for } \\
\text { achievement }\end{array}$ & 9,36 & 27,32 & 4 \\
\hline \multirow[t]{2}{*}{4} & \multirow[t]{2}{*}{ Empathy } & $\begin{array}{l}\text { Sensitive to } \\
\text { other people's feelings }\end{array}$ & 23,26 & 4,6 & 4 \\
\hline & & $\begin{array}{l}\text { Listen to other people's } \\
\text { problems }\end{array}$ & 1,12 & 10,21 & 4 \\
\hline \multirow[t]{2}{*}{5} & \multirow[t]{2}{*}{ Social skills } & $\begin{array}{l}\text { Can work } \\
\text { Together }\end{array}$ & 14,31 & 17,24 & 4 \\
\hline & & Can communicate & 18,20 & 15,34 & 4 \\
\hline & & Total & 18 & 18 & 36 \\
\hline
\end{tabular}

Implementation of the above scale used trial was carried out on 14 to 16 May 2018 for employees at PT. Aspacindo Kedaton Motor that researchers collected during recesses 
totaling 50 people. In the field implementation, the researcher conveys the intent and purpose of conducting research and provides an explanation of how to fill the scale.

Based on the results of the general inspection of the overall answers of the couriers at PT. Aspacindo Kedaton Motor. It is known that all the couriers have given answers according to the charging instructions. The trick is to create a value format based on the scores on each sheet. Then the score which is the subject's choice in the statement item to a computer program is formatted according to the need for tabulation of data, i.e., a column for statement numbers and lines for subject numbers.

Based on the results of trials on conflict management scale items, amounting to 32 statement items, there were 7 statement items that were dropped and 25 valid statement items. Valid statement items have coefficients between 0.338 to 0.606

Table 3. Distribution of Items Distribution Statement of Conflict Management

Scale After Testing

\begin{tabular}{|c|c|c|c|c|c|c|c|}
\hline \multirow{3}{*}{ No } & \multirow{3}{*}{ Aspect } & \multirow{3}{*}{ Indicator } & \multicolumn{5}{|c|}{$\begin{array}{c}\text { Item } \\
\text { Number }\end{array}$} \\
\hline & & & \multicolumn{2}{|c|}{ Favorable } & \multicolumn{2}{|c|}{ unfavorable } & \multirow{2}{*}{$\begin{array}{c}\text { Valid } \\
\text { Total }\end{array}$} \\
\hline & & & Valid & Fall & Valid & Fall & \\
\hline \multirow[t]{2}{*}{1} & \multirow{2}{*}{$\begin{array}{l}\text { Competing or } \\
\text { competition }\end{array}$} & Power-oriented style & - & 9 & 14 & - & 1 \\
\hline & & win the conflict & 4,23 & - & 1 & 26 & 3 \\
\hline \multirow[t]{2}{*}{2} & \multirow{2}{*}{$\begin{array}{l}\text { Kalaborasia or } \\
\text { problem } \\
\text { solving }\end{array}$} & Look for a solution & 18,27 & - & 25,31 & - & 4 \\
\hline & & $\begin{array}{l}\text { accept other people's } \\
\text { opinions }\end{array}$ & 6 & 11 & - & 2,26 & 1 \\
\hline \multirow[t]{2}{*}{3} & \multirow[t]{2}{*}{ Avoidance } & Avoid conflict & 17 & - & 3 & - & 2 \\
\hline & & $\begin{array}{l}\text { Appreciate the } \\
\text { decision }\end{array}$ & 21 & - & 24 & - & 2 \\
\hline \multirow[t]{2}{*}{4} & \multirow[t]{2}{*}{ Accommodation } & $\begin{array}{l}\text { Not concerned with } \\
\text { personal interests }\end{array}$ & 10,12 & - & 8,15 & - & 4 \\
\hline & & Lack of firm & - & 5 & 20 & - & 1 \\
\hline \multirow[t]{2}{*}{5} & \multirow[t]{2}{*}{ Compromise } & $\begin{array}{l}\text { Looking for a } \\
\text { middle ground }\end{array}$ & 28 & 19 & 13,29 & - & 3 \\
\hline & & $\begin{array}{l}\text { Ability to negotiate } \\
\text { listening well }\end{array}$ & 7,30 & - & 22,32 & - & 4 \\
\hline \multicolumn{3}{|c|}{ Total } & 12 & 4 & 13 & 3 & 25 \\
\hline
\end{tabular}

Furthermore, based on the results of the emotional intelligence scale trial totaling 36 statement items, it is known that there are 7 statement items that fall and 29 item statements are valid. A valid statement item has an intermediate correlation coefficient 0.290 to 0.655 . After the items are analyzed with the Product Moment Analysis technique then proceed with the reliability analysis of the emotional intelligence scale. 
Table 4. Distribution of Items Distribution Statement Emotional Intelligence Scale after the Trial

\begin{tabular}{|c|c|c|c|c|c|c|c|}
\hline \multirow{3}{*}{ No } & \multirow{3}{*}{ Aspect } & \multirow{3}{*}{ Indicator } & \multicolumn{5}{|c|}{ Item Number } \\
\hline & & & \multicolumn{2}{|c|}{ Favorable } & \multicolumn{2}{|c|}{ Unfavorable } & \multirow{2}{*}{$\begin{array}{l}\text { Valid } \\
\text { Total }\end{array}$} \\
\hline & & & Valid & Fall & Valid & Fall & \\
\hline \multirow[t]{2}{*}{1} & \multirow[t]{2}{*}{$\begin{array}{l}\text { Self- } \\
\text { awareness }\end{array}$} & $\begin{array}{l}\text { Recognize and understand } \\
\text { your own emotions }\end{array}$ & 7,30 & - & 8,35 & - & 4 \\
\hline & & $\begin{array}{l}\text { Understand the causes of } \\
\text { emotions }\end{array}$ & - & 3 & - & 22 & - \\
\hline \multirow[t]{2}{*}{2} & \multirow{2}{*}{$\begin{array}{l}\text { Self- } \\
\text { regulation }\end{array}$} & Control emotions & 19,29 & - & 16,25 & - & 4 \\
\hline & & $\begin{array}{l}\text { Express emotions } \\
\text { appropriately }\end{array}$ & 2 & - & 5 & - & 2 \\
\hline \multirow[t]{2}{*}{3} & \multirow[t]{2}{*}{ Motivation } & Optimistic & 28,33 & - & 11,13 & - & 4 \\
\hline & & $\begin{array}{l}\text { The drive for } \\
\text { achievement }\end{array}$ & 9 & 36 & 25 & 32 & 2 \\
\hline \multirow[t]{2}{*}{4} & \multirow[t]{2}{*}{ Empathy } & $\begin{array}{l}\text { Sensitive to } \\
\text { other people's feelings }\end{array}$ & 23,26 & - & 6 & 4 & 3 \\
\hline & & $\begin{array}{l}\text { Listen to other people's } \\
\text { problems }\end{array}$ & 12 & 1 & 10,21 & - & 3 \\
\hline \multirow[t]{2}{*}{5} & \multirow[t]{2}{*}{$\begin{array}{l}\text { Social } \\
\text { skills }\end{array}$} & $\begin{array}{l}\text { Can work } \\
\text { Together }\end{array}$ & 14,31 & - & 17,24 & - & 4 \\
\hline & & Can communicate & 20 & 18 & 15,34 & - & 3 \\
\hline & & Total & 14 & 4 & 15 & 3 & $\begin{array}{l}2 \\
9\end{array}$ \\
\hline
\end{tabular}

A item reliability testing techniques are valid using the Cronbach Alpha formula obtained at 0.749. This means that the scale compiled is declared reliable, that is, it can be relied upon to be used at other times. The following table is the distribution of the scale of conflict management scale after being tested. Then the reliability of the emotional intelligence scale using the Cronbach Alpha formula. The reliability index obtained was 0.891 . Thus the scale of conflict management is stated to be reliable, which can be used at other times in expressing conflict management.

Table 5. Calculation of Reliability

\begin{tabular}{|c|c|c|}
\hline Scale & CronbachAlpha & Information \\
\hline Emotional intelligence & 0,891 & Reliable \\
\hline Conflict management & 0,749 & Reliable \\
\hline
\end{tabular}

Distribution normality test is done to find out whether the distribution of research data has spread normally. The normality test is carried out using the One Sample Kolmogorov Smirnov Test. As a criterion if $\mathrm{p}>0.05$ then the distribution is declared normal. Conversely, if $\mathrm{p}<0.05$, the distribution is declared abnormal (Hadi and Pamardi Ningsih, 2000). The following table summarizes the results of the distribution normality test.

Table 6. Summary of Calculation Results for the Distribution Normality Test

\begin{tabular}{|c|c|c|c|c|c|}
\hline Variable & Average & K-S & SD & Sig & Information \\
\hline Kecerdasan emosional & 88,82 & 0,818 & 10,385 & 0.515 & Normal \\
\hline Conflict management & 74,66 & 0,644 & 6,056 & 0.802 & Normal \\
\hline
\end{tabular}


Information :

$$
\begin{array}{ll}
\text { Average } & =\text { Average Score } \\
\text { K-S } & =\text { Kolmogorov and Smirnov coefficients } \\
\text { SD } & =\text { Standard Deviation } \\
\text { Sig } & =\text { Significance }
\end{array}
$$

Linearity test is intended to determine the degree of relationship between the independent variable and the dependent variable. This means that whether emotional intelligence is associated with high conflict management and this can be explained visually by looking at linearity, ie increasing or decreasing the value of the y-axis (conflict management) with increasing or decreasing the value of the $x$-axis (emotional intelligence).

Based on the linearity test, it can be seen whether the independent variable with the dependent variable, can or is not analyzed in correlation. As a criterion if $p>0.05$, it is stated to have a degree of linear relationship (Hadi, 2000). The analysis shows that the independent variable (emotional intelligence) has a linear relationship to the dependent variable (conflict management). The following table summarizes the results of the distribution linearity test.

Table 7. Summary of Calculation Results for Linearity Test

\begin{tabular}{|c|c|c|c|}
\hline Correlational & $\begin{array}{c}\text { F } \\
\text { Different }\end{array}$ & $\begin{array}{c}\text { P } \\
\text { Different }\end{array}$ & Informastion \\
\hline $\mathrm{X}-\mathrm{Y}$ & 3,463 & 0,597 & Linear \\
\hline
\end{tabular}

Information :

$\mathrm{X} \quad=$ Emotional intelligence

$\mathrm{Y} \quad=$ Conflict management

F Different $\quad=$ Linearity Coefficient

P Different $\quad=$ Proportion of Opportunities for Errors

Based on the analysis of the product moment correlation analysis method, it is known that there is a significant positive relationship between emotional intelligence and conflict management, where $=0.772 \mathrm{P}<0.05$. This means that the higher the emotional intelligence, the higher the conflict management and vice versa. The determinant coefficient () of the relationship between the independent variable $(\mathrm{x})$ and the variable $(\mathrm{y})$ is $=0.596$. This shows that the existence of conflict management is formed by emotional intelligence at $59.6 \%$ while the remaining $40.4 \%$ is in other factors not examined in this study.

Table 8. Calculation results for Product Moment Correlation Determinant Coefficient ()

\begin{tabular}{|l|c|c|c|c|c|}
\hline Statistics & Coefficient & Determinat Coeficient & P & BE\% & Inf \\
\hline $\mathrm{X}-\mathrm{Y}$ & 0,772 & 0,596 & 0,000 & $59,6 \%$ & Sig \\
\hline
\end{tabular}

Information :

$\mathrm{X} \quad=$ Emotional intelligence

$\mathrm{Y} \quad=$ Conflict management

$\mathrm{r}_{\mathrm{xy}} \quad=$ Coefficient of Relationship between $\mathrm{X}$ and $\mathrm{Y}$

$\mathrm{r}^{2} \quad=$ Determinant Coefficients $\mathrm{X}$ and $\mathrm{Y}$

$\mathrm{BE} \%=$ The effective contributions of $\mathrm{X}$ and $\mathrm{Y}$ in percent

Variable emotional intelligence, the number of items used are 29 items formatted with a Likert scale in 4 answer choices, then the hypothetical mean is $\{(29 \times 4)+(29 \times 1)\}: 2=72.5$ and the hypothetical mean for variables conflict management is $\{(25 \times 4)+(25 \times 1)\}: 2=$ 62.5 . 


\section{a. Empirical Mean}

Based on data analysis, it is known that the empirical mean of emotional intelligence is with an average value of 88.82 and the average value of conflict management is 74.66.

b. Criteria

In an effort to determine the condition of emotional intelligence and conflict management, it is necessary to compare the mean / empirical mean value with the mean / hypothetical mean value by taking into account the magnitude of the SD numbers. The SD number for emotional intelligence variable is 10.38 and conflict management is 6.056.

From the magnitude of the SD numbers, then if the mean / hypothetical average value <mean / empirical mean value, where the difference exceeds 10.38, it is stated that emotional intelligence is high and if the mean / hypothetical mean value> mean / empirical average value, where the difference exceeds 10.38 then it is stated that intelligence emotionally low. If the mean / empirical mean value with a hypothetical mean does not disagree more than 10.38 , then emotional intelligence is stated as being moderate.

Furthermore, for the conflict management variable of the magnitude of the SD numbers, then if the mean / hypothetical mean value <the mean / empirical average value, where the difference exceeds 6.056, it is stated that conflict management is high and and if the mean / hypothetical mean value> mean / empirical average value, where the difference exceeds 6.056, it is stated that conflict management is low. If the mean / empirical mean value with a hypothetical mean does not disagree over 6.056, then the conflict management is stated to be of moderate criteria.

Table 9. Results of Calculation of Hypothetical Average Values and Empirical Average Values

\begin{tabular}{|c|c|c|c|c|}
\hline \multirow{2}{*}{ Variable } & \multirow{2}{*}{ SD } & \multicolumn{2}{|c|}{ Average value } & \multirow{2}{*}{ Information } \\
\cline { 3 - 4 } & 10,38 & 72,5 & 88,82 & Tinggi \\
\hline $\begin{array}{c}\text { Intelligence } \\
\text { emotional }\end{array}$ & 6,056 & 62,5 & 74,66 & Baik \\
\hline $\begin{array}{c}\text { Management } \\
\text { conflict }\end{array}$ & & &
\end{tabular}

Based on the comparison of the two mean values above (hypothetical mean and empirical mean), it can be stated that emotional intelligence and conflict management are expressed high.

Based on the results of this study it is known that there is a significant relationship between emotional intelligence with conflict management. This result is known from rxy = 0.772 with $\mathrm{P}<0.05$. Based on statistical test results obtained $\mathrm{P}=0.000$, which means the hypothesis proposed in the study there is a positive relationship between emotional intelligence with conflict management in employees at PT. Aspacindo Kedaton Motor, the higher the emotional intelligence the higher the conflict management, conversely the lower the emotional intelligence the lower the conflict management.

Based on the results of research conducted on employees at PT. Aspacindo Kedaton Motor, the hypothesis proposed is accepted.

From this study it is known that the emotional intelligence variable contributes effectively to conflict management by $59.6 \%$. This means that there are still $40.4 \%$ influences from other factors not revealed in this researcher. According to Wirawan, (2010) defines conflict management as the process of a party involved in a conflict or a third party devising a conflict strategy and implementing it to control the conflict in order to produce the desired resolution. The aspects of conflict management according to Robbins (2002) are competition 
or competition, collaboration or problem solving, avoidance, accommodation, and compromise.

Reviewing the results of research through empirical data on emotional intelligence is with an average value of 88.82 and the average value of conflict management is 74.66. In addition, the hypothetical mean value for the emotional intelligence variable was 72.5 and the hypothetical for conflict management variable was 62.5. From these results it can be seen that emotional intelligence and conflict management in employees at PT. Aspacindo Kedaton Motor is relatively high.

Based on empirical data that has been found that it is known that emotional intelligence at PT. Aspacindo Kedaton Motor is classified as high, this is evidenced by the empirical data that has been obtained in the field.

From the results of observations and interviews with informants stated that, relationships between coworkers can often lead to conflict. One of the conflicts that often occur such as data gaps received about the position of assets (motorcycle sales) and delays in information, thus slowing the completion of work and ordering goods needed by the community. Furthermore, the resource person stated that at PT. Aspacindo Kedaton Motor explained, no less than $50 \%$ of all employees experienced conflicts. Some employees have even experienced conflicts since working for a month or two and continue to this day.

\section{Conclusion}

There is a significant positive relationship between emotional intelligence and conflict management. This result is proved by the coefficient of rxy correlation of 0.772 with $\mathrm{P}=$ $0.000<0.05$. This means that the higher the emotional intelligence, the better the conflict management. Based on these results, it means that the proposed hypothesis which says there is a relationship between emotional intelligence and conflict management among employees is accepted.

The effective contribution of the variable emotional intelligence to conflict management in employees amounted to $59.6 \%$. Based on this research it can be seen that there are still $40.4 \%$ influences from other factors on conflict management that were not revealed in this study.

In general, the results of research on employees who have high conflict management and emotional intelligence are also classified as high. This can be seen from the SD results of 6.056, the hypothetical mean value of conflict management at 62.5, and the empirical mean of 74.66. Furthermore, the results of elementary emotional emotional intelligence amounted to 10.38 , the mean hypothetical value was 72.5 and the empirical mean was 88.82 .

\section{References}

Arikunto. S, (2002). Prosedur Penelitian. Jakarta: PT Rineka Cipta

Arikunto, S (2006). Prosedur Penelitian Suatu Pendekatandan Praktek. Jakarta: PT Rineka Cipta.

Azwar. S, (2010). Realibilitas dan Validitas Edisi ke-3. Yogyakarta : Pustaka Pelajar.

Azwar. S. (2005). Metode Penelitian, Yogyakarta: Pustaka Pelajar

Azhar, A. (2018). Marketing of Political Communication Created by NationalMandate Party (PAN) in General Election 2005-2015, North Sumatra, Indonesia. Budapest International Research and Critics Institute (BIRCI-Journal), P. 93-106.

B. Uno, Hamzah. (2008). Model Pembelajaran, Jakarta: PT. Bumi Aksara 
Casmini. (2007). Emotional Parenting (Dasar-Dasar Pengasuhan Kecerdasan Emosi Anak). Yogyakarta: Nuansa Aksara.

Cooper, R.K. and Sawaf, A. (1998).Kecerdasan Emosional Dalam Kepemimpinan dan Organisasi. Alih Bahasa Tita M Kanita. Jakarta: PT Gramedia Pustaka Utama.

Devi Sari Nastiti. Fitri Andriani (2014). Hubungan antara Kecerdasan Emosional dengan Gaya Manajemen Konflik pada Wanita Dewasa Awal yang Telah Menikah. Jurnal Psikologi Klinis dan Kesehatan Mental (Vol. 3, No.3). Hlm. 113-119.Diakses darihttp://journal.unair.ac.id/downloadfullpapers- jpkk5fb947a943full.pdf. Pada tanggal 02 April 2016. Pukul 11.02 WIB

Dermawan. (2013). Metode Penelitian Kuantitatif. Bandung: Remaja Rosdakarya.

Erfika. (2009). Hubungan Kecerdasan Emosi dengan Kecemasan Menghadapi Pensiun pada Karyawan PT. perkebunan Nusantara III Di Kebun Silau Dunia Kabupaten Simalungun. Sekripsi Universitas Medan Area. Tidak diterbitkan

Goleman, D. (1997). Emotional Intellegence. Alih Bahasa Tri Maya. Jakarta: Gramedia Pustaka Utama.

.(2001). Working With Emotional Intellegent. Alih Bahasa Edi Efendi Jakarta: Gramedia Pustaka Utama. .(2002). Working With Emotional Intelligence. Jakarta: PT Gramedia pustaka utama. .(2005).Kecerdasan Emosional Untuk Mencapai Puncak Prestasi, terj.

Alex Tri Kantjono.(2005).Jakarta:PT Gramedia Pustaka Utama. Kecerdasan Emosional. Binuscareer : Jakarta 